\title{
DOI: $10.33193 /$ JALHSS.68.2021.516 \\ Ethics of the Health Practitioner in Profession Ethics Courses of Medical Colleges at the University of Tabuk
}

\author{
Mohammed Abdelraouf Attia \\ Professor, Department of Education Foundations, King Khaled University, Saudi Arabia \\ Email: mabdelraouf75@gmail.com
}

\begin{abstract}
Abdel Mohsen Ibrahim Hashim
Professor, Department of Languages and Translation, University of Tabuk, Saudi Arabia Email: a.ibrahim@ut.edu.sa
\end{abstract}

AB Rashid Mir

Assistant Professor, Department of Medical Lab Technology, University of Tabuk, Saudi Arabia Email: rashid@ut.edu.sa

Ali Hussain Najmi

Associate Professor, Department of Education and Psychology, University of Tabuk, Saudi Arabia Email: a.najmi@ut.edu.sa

Mohammed Abdel Salam Alajamy

Professor, Chair of the Foundations of Education Department, Alazhar University, Egypt

Email: m.alajamy@yahoo.com

Habab A. Othman

Assistant Professor, Department of Education and Psychology, University of Tabuk. Saudi Arabia Email: h-othman@ut.edu.sa

Suhad mohammad Rashed Alatwi

A postgraduate student at the University of Tabuk. Saudi Arabia

Email: twijri@outlook.sa

\section{ABSTRACT}

Health professions belong to the human and ethical professions that require practitioners to be fully aware of ethics and to take into account the patients' conditions and absolute benefit. Saudi Commission for Health Specialties (SCFHS) issued the Code of Ethics of the Health Practitioner (2011) with the aim of sensitizing its target segments to their assigned tasks to achieve the health professions the best level. Since the students of the medical and health colleges are the most important of these segments, this study aimed to: (1) identify the professional ethics included in the Code of Ethics of the Health Practitioner, (2) reveal the extent to which the profession ethics courses offered at the medical and health colleges at the University of Tabuk respond to this code of ethics, and (3) propose some procedures to provide students with these ethics. After analyzing the content of these charters of ethics and courses, the results of the study showed that all national charters as well as international Islamic ones contain many ethics related to the health practitioner towards himself/herself, the patient, his/her profession, his/her colleagues, his/her institution, and his/her society. However, it was found that the students of the medical and health colleges at the University of Tabuk have not studied these ethics. Accordingly, the study proposed some procedures for teaching a course on "the Ethics of the Medical and Health Professions."

Keywords: Profession Ethics, Health Practitioner, Content Analysis, University of Tabuk. 


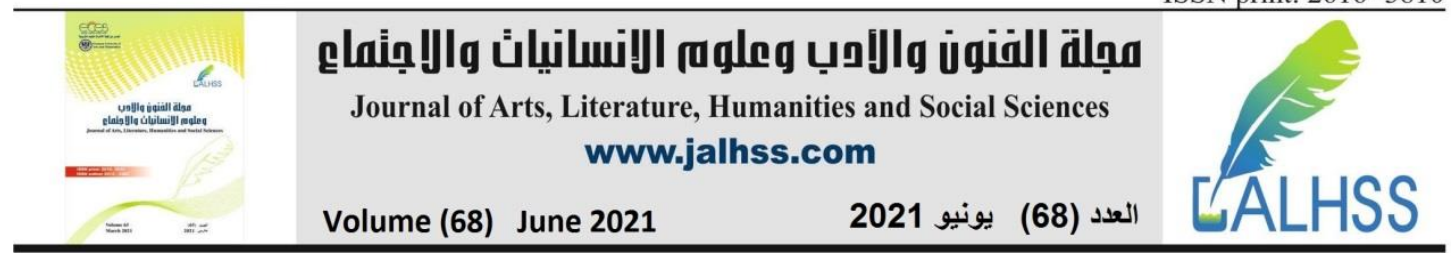

Introduction to the Study Problem:

Contemporary scholars were interested in profession ethics during the 1970s and 1980s. This concern may have been due to the public's attention to the unethical behavior of the workers, and the spread of news on many issues of bribery, espionage, ethical scandals, nepotism, disclosure of confidential information, and many other affairs. Consequently, interest in ethics is now growing in a remarkable way, with people across the globe constantly repeating ethical terms in their relationship to professions, such as: the regulations and ethics of profession, job ethics, business ethics, management ethics, and ethical responsibility in scientific experiments. Various institutions are competing to issue a code of ethics. After efficiency, results, and profit had been the sole focus and the primary goal, ethics is getting more and more attention every day to the extent that governmental institutions and organizations have been mainly interested in issuing new regulations that determine the ethics of work in all various professions ( Alghofiri, Heglawy, \& Elsayed, 2019, p.11).

It is worth noting that Islam has preceded the contemporary societies in emphasizing the ethics of the professions, as Islam has introduced a unique method to life, whether in faith, worship, treatments, or relations among society members in order to achieve happiness to man in the world and the hereafter. Accordingly, Islam has given great importance to the concept of ethics, its status, characteristics, and provisions related to it and its impact on the behavior of the Muslim. Furthermore, Islam considered treating people in a good way as the culmination of correct faith and sincere worship. This is evidenced by the fact that there are 1504 verses in the Holy Qur'an related to ethics, both in its theoretical and practical aspects. Significantly, this number is about a quarter of the number of verses of the Holy Qur'an. In addition, Prophet Mohammed and his companions asserted the importance of ethics and explained in detail how the Holy Qur'an promoted good morals (Alzaidi, 2013, p. 26).

Health professions are considered to be among the human and ethical professions that are mainly based on science and work, necessitating that the person who does these professions must be familiar with them, adequately trained on practice, taking into account the conditions of patients whom he/she deals with, aiming at their absolute benefit.

There is a growing interest in ethics in Muslim societies because Islam urges people to act according to morals and ethics, sincerity and proficiency. Consequently, it is the duty of those who belong to the medical and health professions in particular to consider and act according to these noble values. Therefore, Muslim physicians - such as Ibn Sina, Ibn Alhaytham, Ibn Alnafis, Ali Ibn Issa Alkahhal, Abdul Latif Albaghdadi, Abu Alqasim Alzahrawi, Alharith Ibn Kalda Althaqafi, and Ali Ibn Alabbas - were greatly interested in the profession ethics. They even wrote many books on ethics. For example, Abu Bakr Mohammed Bin Zakaria Alrazi (313 AH/925 AD) devoted a book to profession ethics entitled "Ethics of the Health Practitioner". Besides, the medical books written by Ibn Abi Usai bah (668 AH/1270 AD) included many of these ethics as we can see in his book "The Eyes of News in the Layers of Physicians". Even thinkers and Jurists were interested in this field of ethics. For instance, Ibn Alhaj Maliki (737 AH/1337 AD) 


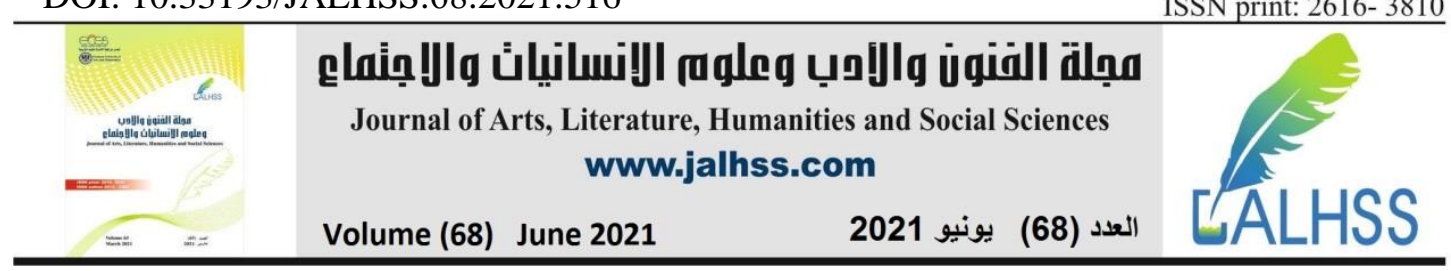

wrote "The Introduction", a book including the ethics of the health practitioner, which is almost a brief overview of what is agreed upon today (Pasha, 2007, pp. 118-138).

The most important of examples are the legal juristic rules presented by jurists for medical issues, such as:

a) Matters are with its purposes, namely: the rules resulting from an order must be based on the requirements of that order. Accordingly, each thing that indicates the patient's consent or agreement is sufficient in obtaining the patient's permission for the doctor to conduct his medical work, and at the same time this does not allow the doctor to perform a procedure that may be apparently acceptable, but has a different purpose.

b) The basic principle in the benefits is permissibility (Halal), and from this rule the jurists authorized the medication of any medicine unless evidence was found that it is forbidden.

c) The basic principle in the defects the prohibition, namely: everything is harmful, it is forbidden in Shari'a. Therefore, it is not permissible to heal in wine, lard, urine, blood, drugs, ...etc

d) The habit is well-established, namely: the rules and actions required by the custom are proven or taken into account if there is no legal text contrary to that custom. Accordingly, if the doctor does the usual procedure and this caused harm to the patient, the doctor does not guarantee it.

e) Certainty does not go away with doubt, namely: the certain thing does not change simply because of doubt. For example, if the sexual organs of a male or a female are complete, it is not permissible to convert them into another gender. But for those whose masculinity and femininity signs meet together, they are medically treated according to their predominant state.

f) Harm or causing harm is forbidden, and therefore it is not permissible to treat with a fraudulent drug, and the doctor cannot be alone with the nurse without necessity, and the doctor may not refrain from patients because of feud or revenge, as it is not permissible to associate the patient with an infectious disease with healthy people; It must be quarantined.

g) Eliminating the damage as much as possible, namely: every effort should be made to prevent the damage before it occurs. Examples include: the possibility of breakfast for a fasting patient, amputation of the eroded organ, abortion, or medication by wearing silk for men, if this would result in the lesser harm.

h) The most severe damage is eliminated with the slightest damage, namely: if two damages are opposed, the greatest damage must be eliminated, even if that requires the lesser damage. Therefore, governments - when there are infectious diseases transmitted through communication - can limit the movement of citizens or set strict prohibition procedures as long as the safety of the majority is involved. The application of this juristic rule also include prohibiting cloning, freezing embryos, or establishing vaccine or semen banks except after conducting accurate assessment of the risks and potential benefits of such activities (Al-Bar, Pasha, \& Al-Bar, 2012, pp. 77-94).

Taking these ethics and jurisprudential rules into account, the Saudi Commission for Health Specialties (SCFHS) issued the Ethics of the Health Practitioner (2011) with 


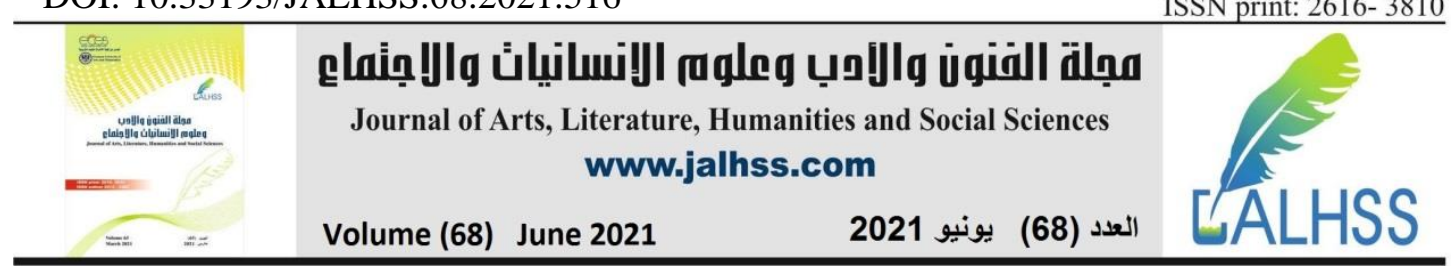

the aim of sensitizing its target segments to their assigned tasks to achieve the health professions the best level.

Although Islam, its scholars, and contemporary societies stress the importance of adhering to the ethics of the professions in general, and the health professions in particular, it is noted - through practice - that there are drawbacks in the commitment to these ethics, especially with regard to the ethics of receiving the patients in a good way, smiling at their faces, avoiding the inferior outlook to some of them, promoting caution against committing legitimate violations, and refraining from treating them. What gives this issue more depth is the importance of contemporary technological development in the ways of diagnosis, treatment, surgery, organ transplants, laboratory fertilization, and other new issues that pose problems and questions that need to be answered and solutions that require reconciling medical progress with the principles of human self-respect, ethics, and religion.

This matter may be further complicated from the Western perspective, Spandorfer, Pohl, Rattner, \& Nasca, (2010) pointed out that physicians and the medical education system have lost their commitment to medical professionalism. The realities of today's medicine, including commercialism, conflicts of interest, decreased autonomy, and increased oversight, have led to the erosion of the idealistic values expected of physicians since the conception of the Hippocratic Oath. This attrition of professionalism has, in turn, led to renewed calls to refine how professionalism is taught in medical education. Despite the calls for change, challenges remain about how an ethos of professionalism should be inculcated in health practitioners' education (p.1).

If all moral, health, economic, and social contemporarily witnessed repercussions and effects of the new epidemic of Corona around the world are added to the above, the anxiety of this epidemic - that has claimed the lives of hundreds of thousands of people increases, and the need to practise the ethics of medical and health professions increases as well. At the same time, the starting point should be from the healthy education of universities as it is the active factor in positive impact and confrontation on one hand, and in making the doctors work with patience, persistence, and interconnectedness on the other one (Habibov \& Cheong, 2017; Merzoev, et al., 2014; Roser, Ritchie, \& Ortiz, 2020).

Therefore, the present study has come to reveal, in general, the ethics of the health practitioner in Saudi Arabia and the extent to which the profession ethics courses presented at the medical and health colleges in the University of Tabuk respond to these ethics.

Specifically, the study seeks to answer the following questions:

1. What are the professional ethics included in the Code of Ethics of the Health Practitioner in Saudi Arabia?

2. How far do the profession ethics courses presented at the medical and health colleges in the University of Tabuk respond to the Code of Ethics of the Health Practitioner in Saudi Arabia?

3. What are the proposed procedures to activate the response of the ethics courses in medical and health colleges at the University of Tabuk to the Code of Ethics of the Health Practitioner in Saudi Arabia? 


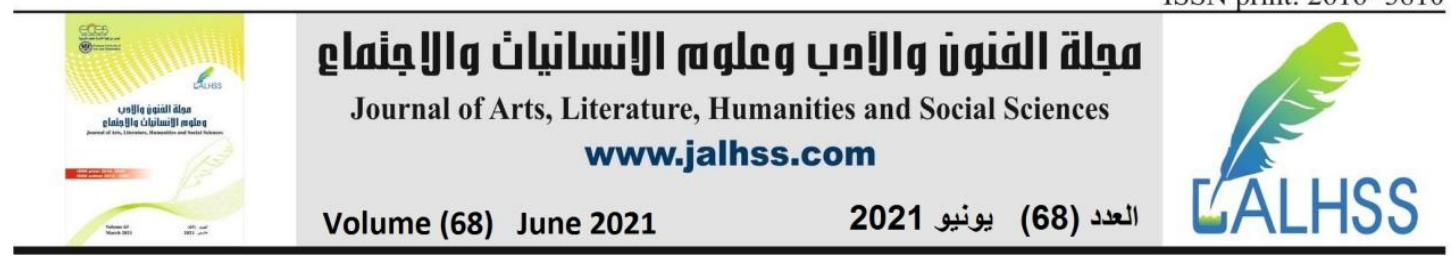

\section{Study Methodology:}

This study used the descriptive method which depends on the collection of data, and then organizing it to describe what is actually taking place as well as the interpretation, analysis, and comparison. The study relied on the content analysis to identify the ethics of the health practitioner in Saudi Arabia and the extent to which the profession ethics courses presented at the medical and health colleges in the University of Tabuk respond to these ethics. To achieve this goal, the study followed a set of steps during the analysis process based on the model of Saldana (2016) and Zhang \& Wildemuth (2009), Which can be clarified through the following:

\section{Preparation of Documents:}

In this step, all documents whose content will be analyzed or those that will contribute to clarifying the relationship of the Code of Ethics of Health Practitioner in Saudi Arabia with other charters have been specified. These documents have been defined as follows:

\section{A. Code of Ethics of the Health Practitioner (2011):}

These ethics were prepared by a committee formed by the decision of the Secretary General of the SCFHS No. 84669 dated 17/3/1432 AH after reviewing and updating the second edition of the book titled "Ethics of the Medical Profession" which was published by the Commission in 1424 AH/2003 AD. This code of ethics consisted of - after the preface - an introduction that shed light on some of the concepts used in this charter (such as: profession ethics, profession regulations, healthcare practitioner, the honor of health professions, and the sources and characteristics of the profession ethics in Islam). Then, this preliminary part was followed by fifteen chapters about: (1) health practitioner ethics, (2-6) health practitioner's duties towards patients, community, professional colleagues, himself/herself, and his/her profession, (7) observance of religious rulings (exposing private parts of the body, abortion, relation between the opposite sexes, healthcare practitioner's relations outside the limits of the profession, and religiously forbidden procedures and treatment methods), (8) ethics of teaching and learning on patients, (9) ethics of documentation and authentication (medical record, certificates and reports, and medical prescriptions), (10) ethics of financial affairs in the healthcare field, (11) ethics of conducting biomedical research and experiments on humans and animals, (12) ethics of dealing with communicable diseases, (13) ethics of dealing with the developments in healthcare practices, (14) ethics of dealing with emergency situations, and (15) ethics of dealing with life-threatening and incurable diseases.

\section{B. Executive Regulation of Health Profession Practice (2017):}

This regulation was issued according to the decision of the Minister of Health No. 4080489 dated 2/1/1439 AH. The regulation consisted of 44 articles distributed over five chapters. These chapters concerned: (1) authorization to practice the profession, (2) the duties of a health practitioner, (3) professional responsibility, (4) investigation and trial, and (5) final judgments. This study was confined to chapter two of the regulation which included 20 articles related to the duties of the health practitioner.

\section{The International Islamic Charter for Medical and Health Ethics (2004):}

This charter consists of 108 articles distributed over ten chapters concerning: (1) the ethics of the doctor, (2) the doctor's duties towards the patient, (3) the medical secret, (4) the doctor's duties towards society, (5) social issues: investing health resources, aids 


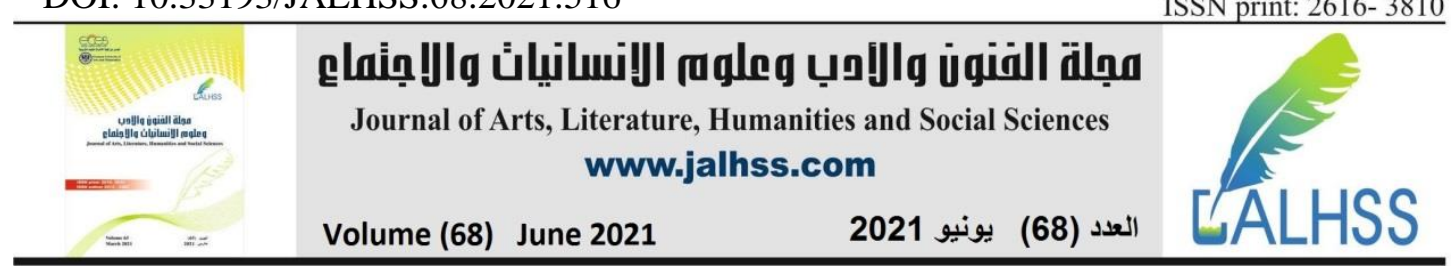

patients and other communicable diseases, facilitating death or the mercy death (Euthanasia), abortion, organ transplantation, and violence cases, (6) advertisements and Publicity in the media, (7) the physician's duties towards the institution in which he/she works, (8) relationships with colleagues, (9) the doctor's rights, and (10) the doctor's duties towards his profession.

\section{Nursing Ethics (NUR 310):}

It is a course presented for the students of the sixth level in the department of Nursing, faculty of Applied Medical Sciences, University of Tabuk.

\section{Defining the Categories of Analysis:}

In this step, after extrapolating the ethics of the health practitioner included in the previous documents, these ethics have been classified into six main categories which are:

a) Ethics of the health practitioner towards himself/herself.

b) Ethics of the health practitioner towards the patient.

c) Ethics of the health practitioner towards his/her profession.

d) Ethics of the health practitioner towards his/her colleagues.

e) Ethics of the health practitioner towards his/her institution.

f) Ethics of the health practitioner towards his/her society.

Each category included a number of sub-categories. After identifying these categories, they were presented to five reviewers to give their views on the comprehensiveness and appropriateness of these ethics. The reviewers' responses confirmed the suitability and validity of this tool in measuring what it was developed for.

\section{Testing the Coding System of Categories by Application on a Sample of Documents:}

In this step, two researchers individually coded the ethics contained in the Code of Ethics of the Health Practitioner in Saudi Arabia. After the analysis, what was coded by the researchers was used to make sure that the analysis was reliable using Holsti's equation $=[(2 \mathrm{x}$ the number of cases agreed in the two encoding times $) /($ the number of cases coded by the first researcher + the number of cases coded by the second researcher)]. In calculating this equation, it turns out that the reliability coefficient ratio was $100 \%$.

\section{Coding All Documents:}

In this step, there was a coding or a quantitative analysis of all the documents prepared for the purpose of achieving the study goals. It should be noted in this context that the aim of the coding was not just to calculate or count frequencies. Rather, the focus was on how far the ethics, in question, were included in the analysis sample.

\section{Drawing conclusions:}

In this step, the findings of the similarities or differences between the professional ethics included in the Code of Ethics of the Health Practitioner in Saudi Arabia and in other charters have been drawn. Besides, a clarification will be given on how far the profession ethics courses presented at the medical and health colleges in the University of Tabuk respond to the Code of Ethics of the Health Practitioner in Saudi Arabia, in order to develop logical explanations for those findings.

\section{Reporting the Findings:}

In this step, the study findings are presented, discussed, and interpreted according to the arrangement of the study questions as follows: 


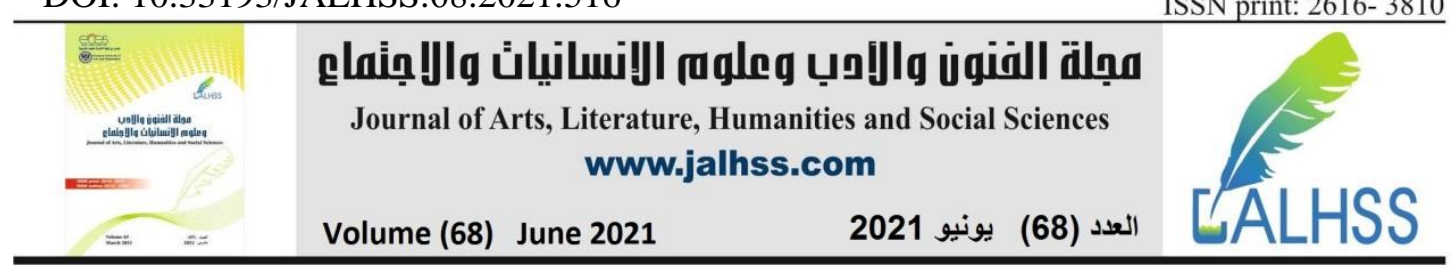

Question 1: What are the professional ethics included in the Code of Ethics of the Health Practitioner in Saudi Arabia?

The content analysis of the Code of Ethics of the Health Practitioner in Saudi Arabia revealed that it includes fifty ethics that can be classified into six main categories, each of which has a number of sub-categories, as shown in the following table:

Table 1: The professional ethics included in the Code of Ethics of the Health Practitioner in Saudi Arabia.

\begin{tabular}{|c|c|}
\hline \multicolumn{2}{|r|}{ First: Ethics of the Health Practitioner Towards himself/herself } \\
\hline 1 & Sincerity in work for Allah Almighty. \\
\hline 2 & To have the sense of watching Allah Almighty in all conditions. \\
\hline $\mathbf{3}$ & To have the sense that Allah will ask him/her about all deeds whether great or minor. \\
\hline 4 & Avoiding trivial things that spoil man's work. \\
\hline 5 & Accustoming oneself to be satisfied. \\
\hline 6 & Protecting oneself from probable dangers while practicing his/her profession. \\
\hline \multicolumn{2}{|r|}{ Secondly: Ethics of the Health Practitioner Towards the Patient } \\
\hline 7 & Well-reception of the patient and smiling at his/her face. \\
\hline 8 & Listening well to the patient's complaint and understanding his/her suffering. \\
\hline 9 & Showing modesty and respect to the patient whatever his/her status is. \\
\hline 10 & Keeping the patient's secrets confidential (except for necessity or a requiring need). \\
\hline 11 & Being patient, gentle and thoughtful with the patient. \\
\hline 12 & Being kind, tender, and soft especially when examining the patient. \\
\hline 13 & Treating the patients fairly and objectively, without discrimination among them. \\
\hline 14 & $\begin{array}{l}\text { Being aware of committing any legitimate violations (such as uncovering naked parts of the } \\
\text { patient's body, or being alone with the opposite sex). }\end{array}$ \\
\hline 15 & Confining the medical treatment of the patient to what his/her condition requires only. \\
\hline 16 & $\begin{array}{l}\text { Being faithful and honest when telling the patient (or the person representing him/her) about the } \\
\text { patient's condition. }\end{array}$ \\
\hline 17 & Informing the patient about his/her condition and how to maintain his/her health. \\
\hline 18 & $\begin{array}{l}\text { Never delaying referring the patient to another person or place that helps in making his/her state } \\
\text { better. }\end{array}$ \\
\hline 19 & Continuing to provide appropriate care and treatment to the patient. \\
\hline 20 & $\begin{array}{l}\text { Providing the patient with the information he/she needs to reassure him/her and remove his/her } \\
\text { fears. }\end{array}$ \\
\hline 21 & Being punctual with the patient and never violating an appointment with him/her. \\
\hline 22 & $\begin{array}{l}\text { Taking the permission of the patient or the person representing him/her before conducting any } \\
\text { medical intervention that may result in probable dangers. }\end{array}$ \\
\hline 23 & Considering and exploring the patient's psychological needs. \\
\hline 24 & Interacting positively with the patient's feelings \\
\hline \multicolumn{2}{|r|}{ Thirdly: Ethics of the Health Practitioner Towards his/her Profession } \\
\hline 25 & Keeping the honor and reputation of the profession. \\
\hline 26 & Sticking to the most possible perfection and competency in practicing the profession. \\
\hline 27 & Developing the profession, scientifically and practically. \\
\hline 28 & Following up on new developments in his/her are of specialty. \\
\hline
\end{tabular}




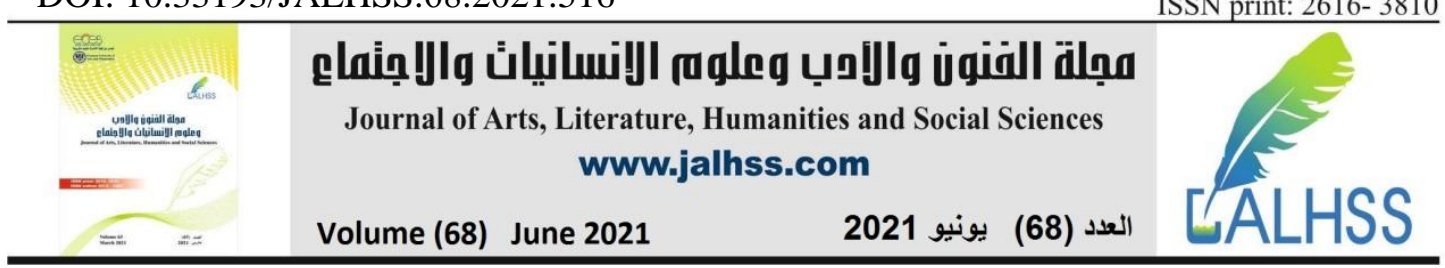

\begin{tabular}{|c|c|}
\hline 29 & $\begin{array}{l}\text { Commitment to professional standards and general ethics while doing professional and other } \\
\text { activities. }\end{array}$ \\
\hline 30 & Sticking to the special regulations governing his/her profession. \\
\hline 31 & $\begin{array}{l}\text { Asking for help in solving the problems that negatively affect the service he/she offers, whenever } \\
\text { necessary. }\end{array}$ \\
\hline 32 & Avoiding the quest for reputation at the expense of the profession's foundations and ethics. \\
\hline & Fourthly: Ethics of the Health Practitioner Towards his/her Colleagues \\
\hline 33 & $\begin{array}{l}\text { Establishing a relationship with colleagues on mutual trust and positive cooperation for the } \\
\text { benefit of patients. }\end{array}$ \\
\hline 34 & $\begin{array}{l}\text { Adopting good behavior with his/her colleagues and treating them as he/she likes them to treat } \\
\text { him/her. }\end{array}$ \\
\hline 35 & Avoiding the dishonest behavior when dealing with other colleagues. \\
\hline 36 & Avoiding the direct criticism of the colleague or underestimating his/her efforts with the patient. \\
\hline 37 & $\begin{array}{l}\text { Transferring his/her experience and skills to his/her colleagues, particularly those who are still in } \\
\text { the training period. }\end{array}$ \\
\hline 38 & $\begin{array}{l}\text { Adherence to accuracy and honesty in evaluating the performance of those who work with } \\
\text { him/her or those who are still in the training period. }\end{array}$ \\
\hline 39 & $\begin{array}{l}\text { Adherence to Shari'a rules when dealing with colleagues (e.g. avoiding being alone with foreign } \\
\text { women.( }\end{array}$ \\
\hline & Fifthly: Ethics of the Health Practitioner Towards his/her Institution \\
\hline 40 & Keeping the reputation of the institution he/she works in. \\
\hline 41 & Contributing effectively to developing and promoting the institution he/she works in. \\
\hline 42 & Preserving the institution's properties and using them well. \\
\hline 43 & Sticking to the laws, regulations, and instructions of the institution he/she works in. \\
\hline 44 & $\begin{array}{l}\text { Adherence to accuracy and integrity (following scientific and administrative principles) when } \\
\text { issuing any reports, certificates or documents or when dealing with the files of patients in the } \\
\text { institution he/she works in. }\end{array}$ \\
\hline & Sixthly: Ethics of the Health Practitioner Towards his/her Society \\
\hline 45 & Being a good model for others (in his/her morals, reputation, speech, and acts). \\
\hline 46 & $\begin{array}{l}\text { Educating the community on the proper methods of dealing with environmental and social } \\
\text { pathogens. }\end{array}$ \\
\hline 47 & Improving the standards and quality of health services offered to the community. \\
\hline 48 & Participating effectively and positively in enacting regulations and developing health policies. \\
\hline 49 & $\begin{array}{l}\text { Participating effectively and positively in preventive, curative, and environmental protection } \\
\text { programs. }\end{array}$ \\
\hline 50 & $\mathrm{n}$ in any practices that harm the community or violate human rights. \\
\hline
\end{tabular}

As noted in the above table, all the professional ethics included in the Code of Ethics of the Health Practitioner in Saudi Arabia are sourced from the glorious guidance of Islam and from the teachings of the Islamic Sharia which call for morality, good work performance, and watching God Almighty in every word and deed, as Prophet Muhammad, may the mercy and blessings of God be upon him, said: "I have only been sent to perfect the best of manners" (Al-Bayhaqi, 2003, p. 323). 


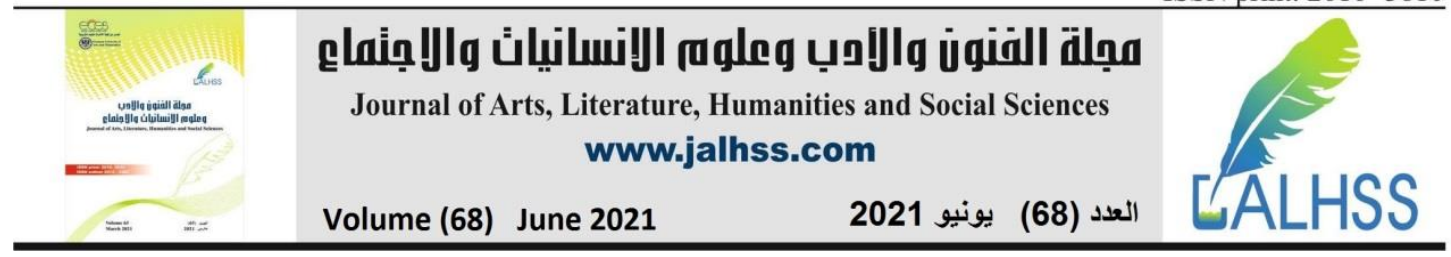

When the companions of the Prophet and the early Muslims understood this goal, and when their association with the Islamic religion and its ethics was closely linked to the lives they led and was confirmed by the witness of the non-Muslim fair-minders, our ancestors could provide benefit for the entire world and stood as good models for their present and future. They could outstandingly achieve this status through applying the teachings of Islam on one hand, and interacting positively with the developments of civilization in all fields of life on the other one. All this was done within the framework of respect for the human rights guaranteed and protected by Islam which made all these rights the main purposes of the great Islamic law in order to preserve religion, soul, offspring, dignity, mind, and wealth.

Following the innovations of Muslim physicians in writing the ethical codes of the health practitioner that began more than ten centuries ago, the reader of Alrazi's "Ethics of the Health Practitioner", for example, finds that the first note Alrazi drew attention to is the ethical contract between the physician and his/her patients. Addressing the physician, Alrazi says, "That person [the patient] trusted you, depended on you, and made you honest for his/her soul". Here, Alrazi points the physician out to meet the patient's confidence with a kind of responsibility when s/he deals with that patient. Alrazi was also keen to alert physicians to be gentle and tender with their patients and to keep their secrets which they only reveal to these physicians. Alrazi expresses these meanings when he writes, "My son [meaning the physician], you have to know that the physician should be gentle with the people s/he treats, and should keep their secrets which they disclose only to him/her and not even to their fathers, mothers, or children" (Khunji, 2019).

This also is what Ibn Abi Usai bah (1998) expressed by mentioning that among the physician ethics are: having a good nature and a right understanding, eager to learn this industry, talking well, providing true opinion when advising, brave, disliking silver and gold, possessing himself in anger, Partner of the ill, and keeping the patients' secrets (p.45).

If the ethics of the health practitioner shown in Table (1) are identical to what was mentioned eleven centuries ago, the analysis of the second chapter which included 20 articles on the duties of the health practitioner in the Executive Regulation of Health Profession Practice (2017) and the analysis of the articles of the International Islamic Charter for Medical and Health Ethics (2004) indicates that both the Executive Regulation of Health Profession Practice (2017) and the International Islamic Charter for Medical and Health Ethics (2004) are also identical to the ethics of the health practitioner shown in Table (1). Perhaps this is due, in the first place, to the derivation of such ethics from the sources of Islamic legislation which are, unlike other legislation sources, characterized with sanctity, humanity, originality, contemporaneity, moderation, realism, comprehensiveness, ...etc.

In addition, The healthcare profession - in Islam - has become one of the noblest professions because it is related to human soul, health, and life preservation which is the most precious thing. The is emphasized in the Holy Quran when Allah said: "Because of that, We decreed upon the children of Israel that whoever kills a soul unless for a soul or 


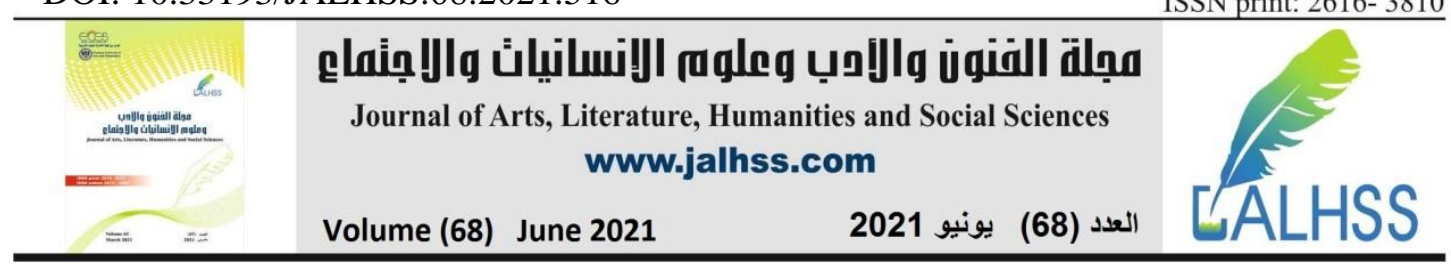

for corruption done in the land - it is as if he had slain mankind entirely. And whoever saves one - it is as if he had saved mankind entirely" (Surat Al-Ma'idah, 5:32).

The convergence of the health practitioner's ethics described in Table (1) with the other two charters can also be interpreted in the light of the Education Policy Document in Saudi Arabia (1995) which affirms that among the general foundations of education are the following:

1. Islam - the formal religion of the Kingdom which is seen as the integrated faith, worship, ethics, rule, and system of life - is the fundamental source of legislation.

2. The mission of Prophet Mohammed is the most perfect approach to the virtuous life that achieves happiness for human beings, and saves humanity from the corruption and misery it has fallen in.

3. Guiding knowledge and sciences of all kinds and resources towards an Islamic insight in addressing its issues and judging its theories, so that they emanate from Islam, and become consistent with the full Islamic perception of existence, universe, man, and life.

4. Benefiting from all kinds of useful human knowledge in order to develop the nation and raise the standard of life as Islam simply asserts wisdom is the ultimate goal of the believer.

5. Life is just a stage of production and work, in which a Muslim invests his energies to get ready for the eternal life in the hereafter.

6. Belief in human dignity asserted in the Holy Qur'an as God says, "We have honoured the Children of Adam and carried them on land and sea, and provided them with good things, and preferred them greatly over many of those We created" (Surat Al-Isra,verse, 17:70).

Question 2. How far do the profession ethics courses presented at the medical and health colleges in the University of Tabuk respond to the Code of Ethics of the Health Practitioner in Saudi Arabia?

Some people may think that the fields of science that rely on applied research and experiment such as the medical field have no ethics or values, but are merely experiments whose only goal is benefit in its materialistic sense, which means the separation of these fields from the system of values and ethics. In fact, this belief needs to be reconsidered in such areas and practices in the light of the system of values and ethics. This is because practice cannot be separated from a base of ethics that guides behavior and controls its path. Hence, presenting courses that are concerned with the ethics of the medical and health professions, particularly if this goes in harmony with the philosophy of Saudi universities which aims at forming the Muslim person in a way that promotes ethics and morals in this person as well as developing him/her culturally and scientifically, is of great importance. From an Islamic perspective, it is impossible to separate science from religion on one hand. On the other hand, this issue is very important for revealing the extent to which the profession ethics courses presented at the medical and health colleges in the University of Tabuk respond to the Code of Ethics of the Health Practitioner in Saudi Arabia.

Reviewing the study plans of the medical and health colleges at the University of Tabuk, such as Faculty of Medicine, Faculty of Pharmacy, and Faculty of Applied 


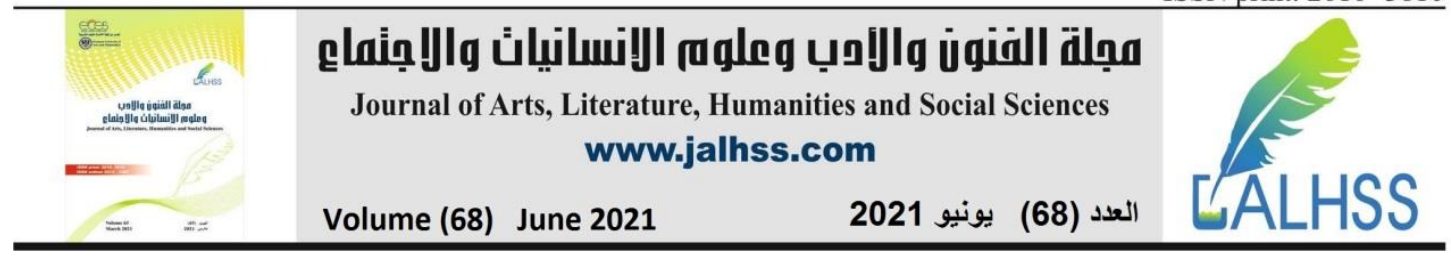

Medical Sciences with its three departments (Medical Laboratory Technology Department, Physical Therapy Department, Nursing Department), it was found that these study plans do not present any course concerned with ethics of the medical and health Professions except only one course on "Nursing Ethics" coded NUR 310.

Analyzing the specification of this course according to the form of the National Center for Assessment and Academic Accreditation (NCAAA), it was noted that it is a theoretical mandatory course (two hours), presented for the students of the sixth level, Department of Nursing, Faculty of Applied Medical Sciences, University of Tabuk.

Generally, this course deals with basic and advanced concepts and principles of Bioethics. It includes reflections on moral experiences, sensitizations to ethical considerations and issues in patient care, community work and public issues and responsibilities. It also entails continuous learning and applications of ethics in the practice of professional nursing.

Specifically, the course aims to promote the skills of reasoned argument by developing knowledge and understanding of ethical and legal frameworks and their impact on health care settings. By the end of the course, students should be able to:

1. Know the definitions and major concepts in ethics.

2. Understand the ethical approach to decision making.

3. Understand the importance of bioethics to the profession.

4. Differentiate ethics form bioethics.

5. Discuss various moral theories.

6. Define bioethics.

7. Discuss bioethical principles by Beauchamp.

8. Discuss Islamic ethical principles.

9. Apply principles to case scenarios.

10. Present and defend position on ethical issues through debate.

As for the topics included in the course, they are as follows:

UNIT I: General Concepts on Ethics: (Ethics, definition - Ethics and Morality - Law and Ethics - Ethical Dilemma - Moral Theories: Deontology, Consequentialism, Bioethics Cultural Diversity and Ethics).

UNIT II: Bioethics: (Definition - principles of Bioethics by Beauchamp: autonomy, nonmaleficence, beneficence, justice).

Unit III. Other moral frameworks: (Islamic Moral Theories - The West Point Honor Code).

Unit IV: Nurses' Code of Ethics.

Unit V: Trends and Issues in Bioethics: (Most common problems or issues in Bioethics in Tabuk City - Most common problems related to informed consent - Cases Presentation).

Concerning the course learning outcomes, the Knowledge and cognitive skills acquired at the end of that course are to:

1. Understand the dynamics between ethics and the law.

2. Learn how to implement contemporary ethical principles by examining the difference between ideas (duties).

3. Discuss actions (consequences) as they pertain to the principles of ethics. 


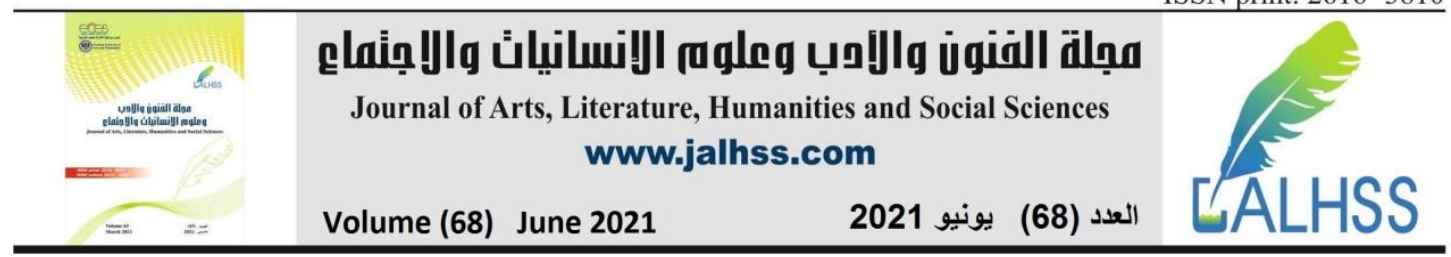

4. Know the common terms and principles of modern bioethics.

5. Understand how to recognize and utilize a decision making model approach to solving ethical dilemmas.

6. Describe how to identify the ethical duties and actions of the health care professional when obtaining an informed consent from a client/family.

7. Describe how to recognize the health care providers ethical responsibilities in safe guarding the contents of medical records.

8. Know why ethics may differ among different cultures and why this knowledge is important.

9. Learn why bioethics needs to be integrated through conscious design in order for the health care provider to deliver ethical care.

10. Discuss the importance of ethics in modern medicine in today's culturally diverse health care environment.

The interpersonal skills acquired at the end of that course are to:

1. Appreciate the importance of working collaboratively with other members of the health team observing ethical-moral responsibilities.

2. Demonstrate sensitivity and right attitude in dealing with clients by having an indepth understanding of nature, support system, and environment of the client.

3. Respect on the patients' bill of rights, cultural practice, values, and decisions towards issues affecting their health.

4. Stewardship over the dignity and personhood of the client.

The psychomotor skills acquired at the end of that course are to:

1. Develop critical thinking in prioritizing actions when faced with ethical dilemmas.

2. Develop decision making skills and ethical communication when confronted with issues affecting the rights, culture, and beliefs of the client in prioritizing nursing actions in the care and management of clients.

3. Demonstrate understanding of different types of educational objectives, development of teaching plans during giving care and counseling in the field of practice.

4. Apply the general principles of instructional material in the nursing practice.

Although the objectives, topics, and outcomes included in the specifications of the "Nursing Ethics" course emphasize the ethics of medical and health professions from both Islamic and Western perspectives, when analyzing the course presented for students in this semester (first semester, 2019) whose title is "Student's Guide to Research Ethics", 2nd Edition, by Paul Oliver (Open University Press, http://site.ebrary.com/id/10403994?ppg=85), it was found that the course is far from the objectives, topics, and outcomes of the profession ethics included in the course specification given above. Rather, it is concerned with the ethical issues related to scientific research in the field of medical and health practices, such as:

a. The privacy of respondents and restrictions on the use of data (anonymity, confidentiality, maintaining the social ecology of a research setting, observational studies in a public setting, privacy in institutions and organizations, the shortage of data). 


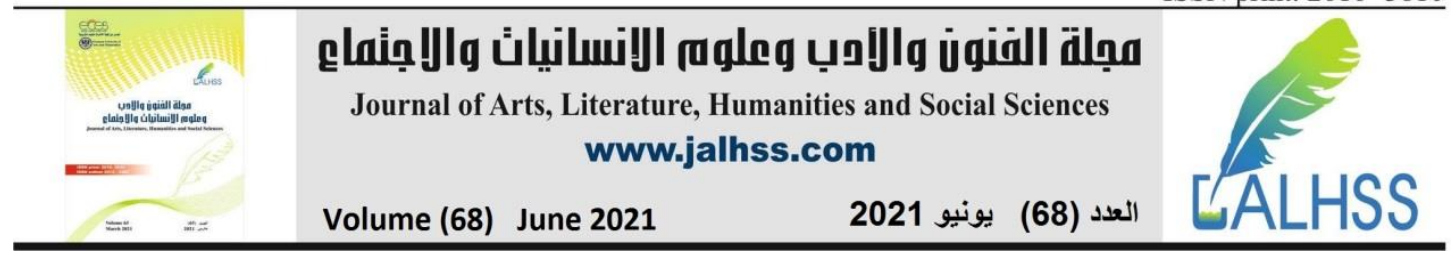

b. Differences in the research context (cultural differences, gender differences, differences of ethnicity, religious differences, the data collection of different respondents, issues specific to research in a health or social care context).

As noted, there is neither similarity between the specifications of the "Nursing Ethics" course and the taught determined course, nor between this course and the ethics of the health practitioner identified in the research.

Question 3. What are the proposed procedures to activate the response of the ethics courses in medical and health colleges at the University of Tabuk to the Code of Ethics of the Health Practitioner in Saudi Arabia?

Analyzing the content of the study sample represented in the Ethics of the Health Practitioner (2011), the Executive Regulation of Health Profession Practice (2017), and the International Islamic Charter for Medical and Health Ethics (2004), the following conclusions were reached:

1. The Code of Ethics of the Health Practitioner (2011) contains fifty ethics of the ethics of the health practitioner towards: himself/herself, the patient, his/her profession, his/her colleagues, his/her institution, and his/her society. These ethics which are emanating from the Islamic religion and the heritage of early Muslim physicians are consistent with the philosophy and educational policy of Saudi Arabia.

2. There is full congruence among the ethics included in the Executive Regulation of Health Profession Practice (2017), the International Islamic Charter for Medical and Health Ethics (2004), and the Code of Ethics of the Health Practitioner (2011).

3. No course on profession ethics in medical and health colleges at the University of Tabuk is offered except only one course on "Nursing Ethics", presented for the students of the Nursing Department at the Faculty of Applied Medical Sciences.

4. The objectives, topics, and outcomes of the nursing ethics course mentioned in the course specification referred to above are concerned with the profession ethics, but the course that was presented in the first semester of the year 2019 was far from its course specification.

According to these findings, and to answer the third question, the study suggests the following:

- Benefiting from the integrative approach in a way that makes all the programs offered in the medical and health colleges at the University of Tabuk include the ethics of the health practitioner, whether in the topics they handle or in the related activities inside or outside the college.

- Offering a course on "the Profession Ethics" for all the departments of the Faculties of Medicine, Pharmacy, and Applied Medical Sciences, provided that the concerned course is offered in one of the last three levels of study.

- Allocating three credit hours for teaching this course, divided into two theoretical hours and one field hour on which every student submits a report at the end of the semester on a visit s/he conducts to a hospital, showing with evidence, the diagnosis, evaluation, or ways to improve one of the ethical issues $\mathrm{s} / \mathrm{he}$ has dealt with during the visit. 


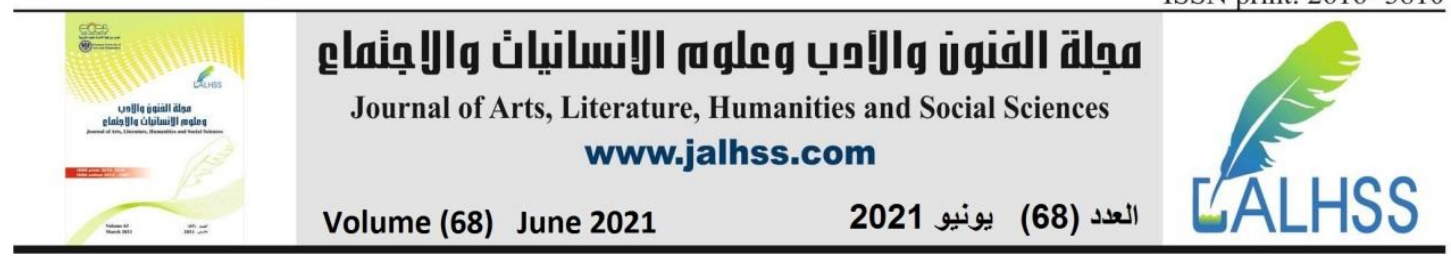

- Defining this course in a single book or reference, whether through competition or through joint composition among the legal, medical and health specializations, provided that the suggested book or reference complies with the objectives, topics, and outcomes mentioned in the course specifications form on one hand, and that it takes into consideration the additional elements proposed in the following table on the other one.

Table (2): Proposed elements to be added to the course of "Profession Ethics" in the Medical and Health Colleges at the University of Tabuk

\begin{tabular}{|c|c|}
\hline Objectives & $\begin{array}{l}\text { 1. To present medical standards to control the ethics and practices of } \\
\text { health professions - especially with medical and research dilemmas } \\
\text { and developments - within the framework of Islamic jurisprudence. } \\
\text { 2. To provide students with the necessary information about the rights } \\
\text { and duties of the health practitioner. } \\
\text { 3. To develop students' attitudes towards the importance of the } \\
\text { commitment to the profession ethics. } \\
\text { 4. To enhance students' skills in dealing with the members of their } \\
\text { professional community. } \\
\text { 5. To educate students about the actions that support the building of a } \\
\text { good professional behavior. } \\
\text { 6. To demonstrate the returned benefit for society from the health } \\
\text { practitioners' commitment to "the social contract between that } \\
\text { profession and society" (trust that healthcare practitioner will be } \\
\text { capable, moral, accountable, and will act in the best interest of those } \\
\text { whom they are serving). }\end{array}$ \\
\hline Topics & 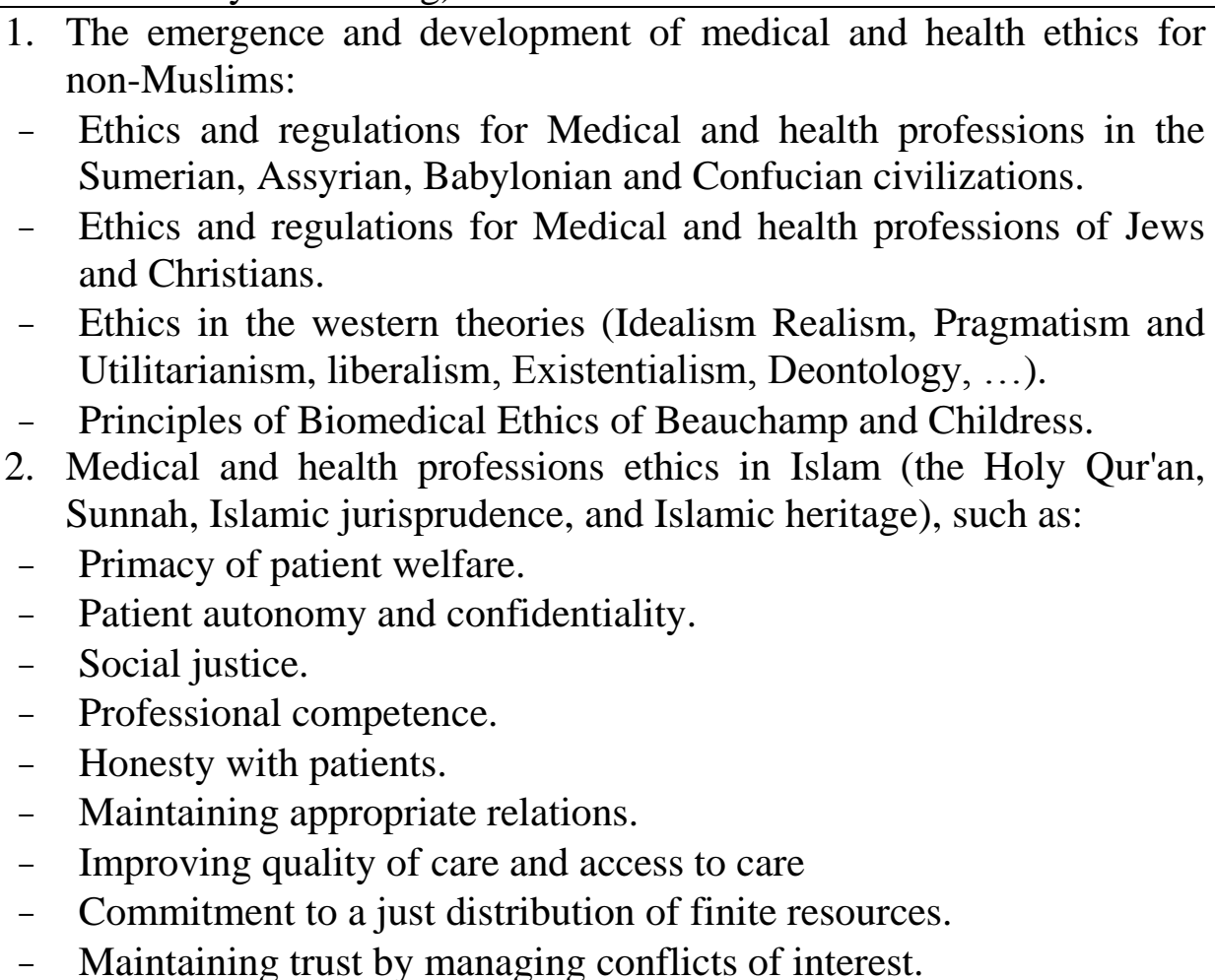 \\
\hline
\end{tabular}




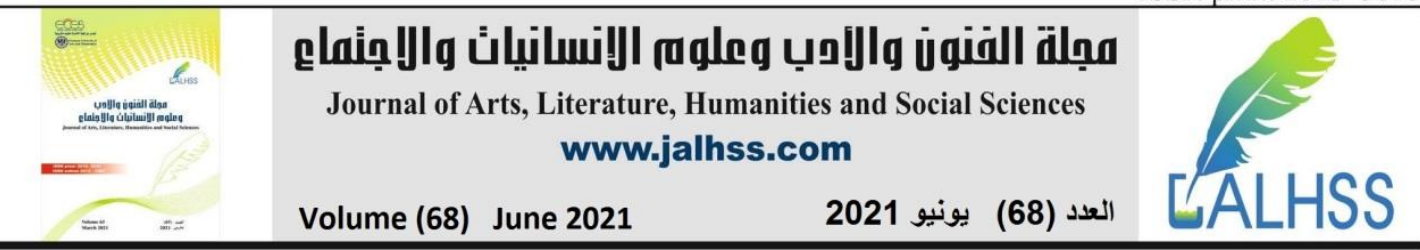

\begin{tabular}{|c|c|}
\hline & $\begin{array}{l}\text { - Commitment to professional responsibilities and Scientific } \\
\text { knowledge. } \\
\text { 3. The applications of jurisprudence rules in the field of medical and } \\
\text { health practices: } \\
\text { - The importance of Jurisprudence rules in the medical and health } \\
\text { fields. } \\
\text { - The relation of medical and health practices to the purposes of the } \\
\text { Sharia: preserving religion, soul, mind, offspring, and wealth. } \\
\text { - Sharia rules and their medical and health applications, such as the } \\
\text { rules of: benefit, intent, damage, hardship, the right and } \\
\text { authorization of others, cooperation and altruism, certainty, and } \\
\text { custom, ...etc } \\
\text { 4. New practices in the medical and health professions between the } \\
\text { ethical and legal responsibility, such as: Taboo medication, } \\
\text { Engineering and genetic diseases, Medical examination before } \\
\text { marriage, Autopsy,Plastic surgery, Hymen atresia, Change of the } \\
\text { fetus sex, Reduction of Pregnancy, High Tech Babies, controlled } \\
\text { medical trials, ...etc } \\
\text { 5. Islamic, international, and local models of the ethical charters of the } \\
\text { medical and health professions. }\end{array}$ \\
\hline & $\begin{array}{l}\text { - Teaching "Medical and health professions ethics" in the explicit } \\
\text { and implicit curriculum. } \\
-\quad \text { Explicit curriculum - occurring mainly during lectures and } \\
\text { manifold sessions or events - ought to: (1) be consistently integrated all } \\
\text { over the study years; (2) be overly simplistic; ( } 3 \text { ) focus more on the ethical } \\
\text { aspects of professionalism (such as using lists of rules and behaviors and } \\
\text { describing the positive and negative consequences of actions); and (4) use } \\
\text { resources or texts about medical professionalism. } \\
\text { - The implicit, or hidden, curriculum consolidates values - that } \\
\text { have been learned in lecture, small groups, ceremonies, and during training } \\
\text { in real-world settings - through ideal first-hand observations and } \\
\text { displaying professional conduct according to the adage "do as I say, not } \\
\text { what I do". } \\
\quad-\quad \text { Using several teaching methods, such as: (1) Problem solving; (2) } \\
\text { Case studies; (3) Action research or research projects; (4) Community/field } \\
\text { visits; (5) Role play/simulation; (6) Small group discussion; and (7) } \\
\text { Isolated events, including the "white coat ceremony.". }\end{array}$ \\
\hline $\begin{array}{l}\text { Proposed } \\
\text { References }\end{array}$ & 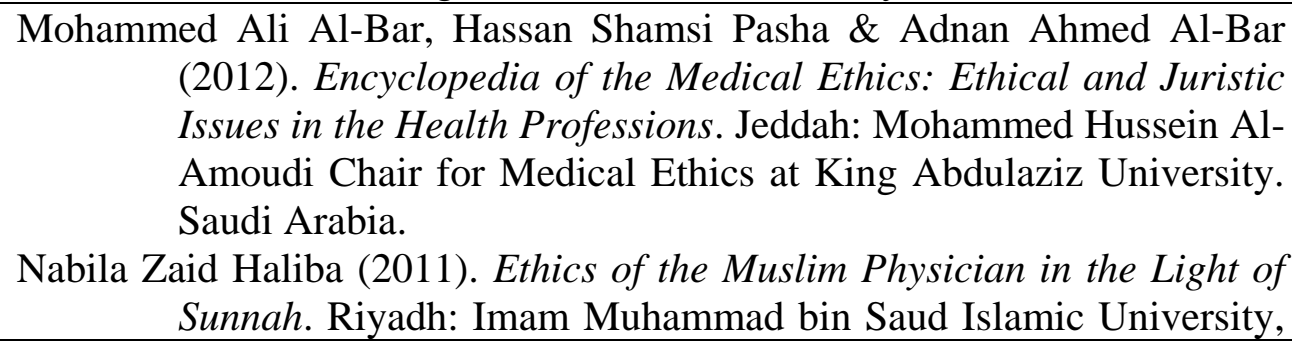 \\
\hline
\end{tabular}




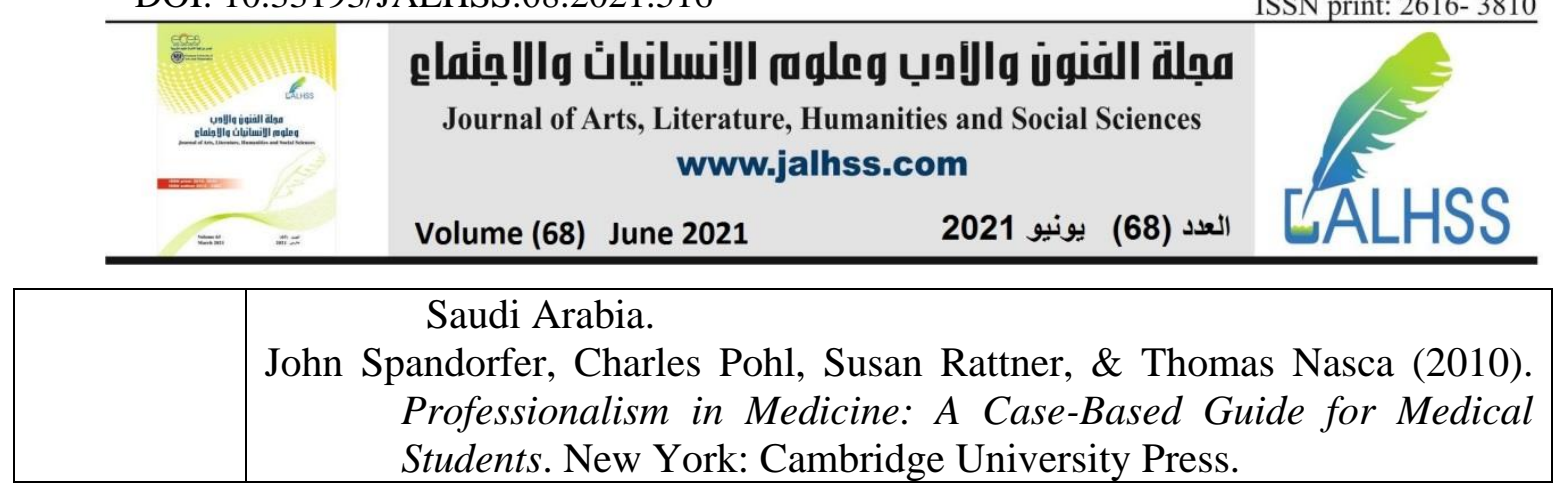

Finally, the study suggests further research on the following points:

- The extent to which the medical cadres in the hospitals of Tabuk City represent the ethics of the health practitioner.

- The Level of awareness of the profession ethics among the students of the medical and health colleges at the University of Tabuk.

- The extent to which the ethics courses in the medical and health colleges in other Saudi universities respond to the ethics of the health practitioner.

\section{Acknowledgment}

The authors would like to acknowledge the financial support for this work from the Deanship of Scientific Research, University of Tabuk, Saudi Arabia. Grant No. S-14400298.

\section{References}

1. Al-Bar, M., Pasha, H., \& Al-Bar, A. (2012). Encyclopedia of the medical ethics: Ethical and juristic issues in the health professions. (Vol. 2). Jeddah: Mohammed Hussein Al-Amoudi Chair for Medical Ethics at King Abdulaziz University. Saudi Arabia.

2. Albayhaqi, A. (2003). Great Sunah. Beirut: Scientific Book House. (In Arabic).

3. Alghofiri, A., Heglawy, L. \& Elsayed, M. (2019). Professional Ethics. Riyadh: AlRushd Library. (In Arabic).

4. Alzaidi, T. (2013). Ethical responsibility in Islamic Fiqh: An analytical empirical study of media ethics in Islamic Honour Charters. Jordan: Dar Al Nafees for Publishing and Distribution. (In Arabic).

5. Boyd, M. (2005). Medical ethics principles, persons, and perspectives - from controversy to conversation. Journal of Medical Ethics, (31), 481-486.

6. Education Policy Document in Saudi Arabia (1995). 3rd ed. Riyadh: Ministry of Education - Supreme Committee for Education Policy, General Secretariat. (In Arabic).

7. Ethics of the Health Practitioner (2011). 3rd ed. Saudi Commission for Health Specialties (SCFHS), Medical Education Administration and Postgraduate Studies, Saudi Arabia. www.scfhs.org.sa. (In Arabic).

8. Executive Regulation of Health Profession Practice (2017). Ministry of Health, Saudi Arabia. (In Arabic).

9. Habibov, N. \& Cheong, A. (2017). The role of university education in selecting active strategies for coping with 2007 global crisis in 28 transitional countries. International Journal of Educational Development, (57), 65-72.

10. Ibn Abi Usai bah (1998). The eyes of the news in the layers of Physicians. Beirut: Scientific Books House. (In Arabic). 


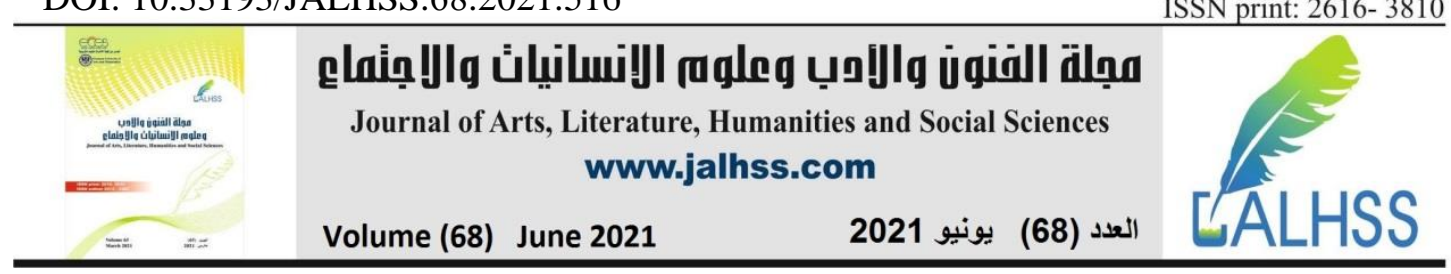

11. International Islamic Charter for Medical and Health Ethics (2004). horizon.hsc.edu.kw/library/resources/Islamic_ethics.pdf. Accessed. 12 Sept. 2019. (In Arabic).

12. Khunji, Z. (2019). Ethics of a Physician. http://www.akhbaralkhaleej.com/assets/fonts/fonts.css. Accessed. 24 Oct. 2019. (In Arabic).

13. Mirzoev,T., Le, G., Green, A., Orgill, M., Komba, A., Esena, R., Nyapada, L., Uzochukwu, B., Amde, W., Nxumalo, N., \& Gilson, L. (2014). Assessment of capacity for Health Policy and Systems Research and Analysis in seven African universities: Results from the CHEPSAA project. Health Policy and Planning, (29), 831-841.

14. Pasha, A. (2007). Fundamentals of contemporary sciences in Islamic Heritage: An empirical study. Egypt: Family Library. (In Arabic).

15. Roser, M., Ritchie, H., \& Ortiz, E. (2020). Corona Virus Disease (COVID-19) Statistics and Research. Published online at Our World In Data. org. Retrieved from: https://ourworldindata.org/coronavirus [Online Resource].

16. Saldana, J. (2016). The coding manual for qualitative researchers. London: SAGE Publications Inc.

17. Spandorfer, J., Pohl, C., Rattner, S., \& Nasca, T. (2010). Professionalism in medicine: A case-based guide for medical students. New York: Cambridge University Press.

18. Zhang, Y. \& Wildemuth, B. (2009). Qualitative Analysis of Content. In: B. M. Wildemuth, Ed., Applications of Social Research Methods to Questions in Information and Library Science, Libraries Unlimited, pp. 1-12. 